\title{
NURSING STUDENTS' WORK, A RISK FACTOR FOR THE CONSUMPTION OF ALCOHOL AND OTHER DRUGS ${ }^{1}$
}

Elias Barbosa de Oliveira ${ }^{2}$ Antonia Regina Ferreira Furegato ${ }^{3}$

Oliveira EB, Furegato ARF. Nursing students' work, a risk factor for the consumption of alcohol and other drugs. Rev Latino-am Enfermagem 2008 maio-junho; 16(especial):565-71

This descriptive, qualitative study aims to describe risk factors, in the work environment, for the consumption of alcohol and other drugs, and also to confirm the importance of protective factors. Interview technique was used with 51 nursing students at the Rio de Janeiro State University, who work in the city's health services. Results: students related work as a risk factor for the consumption of drugs such as alcohol, cigarettes and anxiolytics. We conclude that working with participative methodologies, valuing student's former experiences, family and group life, and individual characteristics are essential in the preventive approach. Attention to protective factors is recommended.

DESCRIPTORS: nursing; alcoholic beverages; anti-anxiety agents; students, nursing

\section{EL TRABAJO DEL ESTUDIANTE DE ENFERMERÍA COMO UN FACTOR DE RIESGO PARA EL CONSUMO DE ALCOHOL Y OTRAS DROGAS}

Estudio cualitativo descriptivo que tuvo por objetivo describir los factores de riesgo dentro del ambiente laboral para el consumo de alcohol y otras drogas; así como confirmar la importancia de factores de protección. Se utilizó la técnica de entrevista con 51 estudiantes de enfermería de la Universidad del Estado de Río de Janeiro, que se encontraban en los servicios de salud de la ciudad. Resultados: los alumnos consideraron al trabajo como un factor de riesgo para el consumo de alcohol, cigarro y ansiolíticos. Se concluyó que se debe trabajar en la prevención con métodos participativos y valorar las experiencias pasadas de los alumnos, la convivencia familiar y grupal y las características individuales. Fue recomendada especial atención a los factores de protección.

DESCRIPTORES: enfermería; bebidas alcohólicas; agentes ansiolíticos; estudiantes de enfermería

\section{O TRABALHO DO ACADÊMICO DE ENFERMAGEM COMO FATOR DE RISCO PARA O CONSUMO DE ÁLCOOL E OUTRAS DROGAS}

Estudo qualitativo descritivo que objetivou descrever os fatores de risco no ambiente de trabalho para o consumo de álcool e outras drogas, e também ratificar a importância dos fatores protetores. Utilizou-se entrevista com roteiro em 51 acadêmicos de enfermagem da Universidade do Estado do Rio de Janeiro que atuam nos serviços de saúde do município. Resultados: os alunos referiram ao trabalho como fator de risco para o consumo de drogas como o álcool, cigarro e ansiolíticos. Concluiu-se que na abordagem da prevenção, deve-se trabalhar com metodologias participativas e valorizar as experiências pregressas dos alunos, o convívio familiar e grupal, e as características individuais. Recomenda-se atenção aos fatores protetores.

DESCRITORES: enfermagem; bebidas alcoólicas; ansiolíticos; estudantes de enfermagem

${ }^{1}$ Study presented at the IV International Institute in Nursing Leadership and drugs phenomenon in Latin America, Bogota; ${ }^{2}$ RN, PhD in Nursing, Adjunct Professor at Rio de Janeiro State University, Brazil. e-mail: eliasbo@tutopia.com.br; 3 PhD in Nursing, Full Professor, University of Sao Paulo at Ribeirao Preto, School of Nursing, WHO Collaborator Center for Nursing Research Development, Brazil, e-mail: furegato@eerp.com.br 


\section{INTRODUCTION}

National and international studies, as well as reality itself, have shown that drug use and abuse have increased significantly, with severe consequences for the individuals' health and high costs for the health system and society. This situation demands greater attention from both governments and healthcare professionals. Stress, unemployment, violence and precarious healthcare and education assistance conditions are factors with strong social and emotional influence on people's lives, which have a causal or consequential relation with drug abuse ${ }^{(1)}$.

In the healthcare area, nowadays, nursing professionals face a number of situations in their personal and professional lives which cause physical and emotional stress when dealing with the clients' pain and suffering, repetitive and intensive occupational journeys, facing a concrete possibility for the use of psychoactive substances in their work ${ }^{(2)}$.

Such possibility must also be considered for nursing students since, although being temporary workers, they are prone to psychophysical exhaustion due to the academic activities and the fact of experiencing ergonomic, psychosocial and organizational risks at work - factors that can have a causal or consequential relation with drugs consumption. Thus, students, when inserted in the workforce in the practical-theoretical training modality called internship, experience what it is like to be a nurse, with the aggravator of not yet having the qualification and skills required by the organization.

Internships, the training modality adopted by Rio de Janeiro State University (FENF/UERJ) since 1982, aims to offer undergraduate students a reflexive praxis, demanding 40 work hours a week in the healthcare units of the city, under the supervision of professors and nurses. With the changes carried out in the FENF/UERJ undergraduate curriculum in 1996 and the extinction of habilitations, the internship modality was maintained. Practical activities in higher complexity units, including emergency, intensive care and communicable diseases, were included in the curricular program.

With the inclusion of more complex units in nursing education, the students started experiencing situations of obvious psychophysical exhaustion due to little familiarity with the work process, worsened by a lack of decisive power and control. In these circumstances, suffering comes from the permanent tension of having to deal with situations of little or no familiarity, making prevention and development of actions more difficult, as well as facing the problems inherent to the process and unforeseen situations ${ }^{(3)}$.

Thus, possibility should be considered that work is a risk factor for the consumption of drugs by academics as a (dysfunctional) strategy to deal with the pressures of academic life. This behavior, associated with other risk factors (group influence, precedents of dependence in the family, positive expectations regarding the use) ends up facilitating the problems related to consumption ${ }^{(4)}$.

Establishing a cause for the prevalence or consumption of drugs among university students is not the easiest of tasks, due to the many conjugated factors. However, stressing or breaking out factors, such as pressure due to an excessive workload, late financial independence, higher amount of work and responsibilities (the student deals with life, human suffering and even death) besides the deprivation of family life and leisure time, are important factors generating this fact ${ }^{(5)}$.

This research aimed to look at the work of nursing interns as a risk factor for the consumption of alcohol and other drugs, justified by the lack of research discussing this problem in nursing.

The objectives of this study were: to describe the risk factors for the consumption of alcohol and other drugs in the healthcare work environment, which academics are exposed to, and to ratify the importance of protective factors as a prevention strategy for drug use and abuse.

\section{MATERIAL AND METHOD}

This is a descriptive research with a qualitative approach, which allows us to unveil social processes not yet well-known. The project was approved by the Ethics Committee according to Resolution 196/96. When signing the term of consent, it was emphasized that the identity of the subjects interviewed would be preserved, and that they could give up their participation in the study at any time. It was also made clear that the results would be released through articles and presentations in events, with the objective of contributing to research and study in this field.

The semi-structured interview, combining objective (or structured) and open questions was chosen, where the interviewee has the possibility to 
discuss the proposed theme, without answers or conditions being pre-established by the researcher ${ }^{(6)}$. A questionnaire was used with the following contents: in the first part, the sociodemographic profile of the group; in the second part, seven questions about the relation between work and psychoactive substances; and, in the third part, two charts containing data referring to the use and classification of psychoactive substances, so that the interviewees could register their experiences. The interviews happened in a private location at the FENF/UERJ, from 1 p.m. to 4 p.m., in four meetings (groups of up to 15 people). Working with groups was preferable to facilitate the data collection. However, it is important to emphasize that the instruments were filled out individually and that all procedures regarding anonymity were maintained.

Thematic analysis was used to categorize the data, since it is considered the fastest and most effective method, being applied to both direct (manifested) and simple content ${ }^{(7)}$.

\section{RESULTS AND DISCUSSION}

Sociodemographic profile of the subjects

51 academics participated in the study, from the last two periods of the nursing undergraduate course, respecting the adopted inclusion criteria. They are young adults from 21 to 29 years old, most of them (75\%) between 21 and 24 years old. They are undergoing a moment of transition in their lives, mainly regarding family dependence, education, expectations regarding insertion in the workforce and future plans.

Nowadays, it is noticeable that, in most countries, due to economic aspects, the issue of being inserted in the workforce and the consequent financial independence seems to be making "adolescence" last longer in the middle or high income population. While for the lower class of the population, becoming an adult is usually associated with the fact of being able to support oneself economically, there are other rites of passage among middle and high income populations, such as the entrance examination for the university and holding jobs of high social status ${ }^{(8)}$.

The subjects in this study belong to the middle class, with incomes at around five times the minimum wage. They owned the homes they lived in (83\%) and lived with their parents in the city of Rio de Janeiro $(90 \%)$; they were single $(100 \%)$ and female $(83 \%)$; declared themselves white $(61 \%)$, mulatto $(24 \%)$ or black $(9.5 \%)$. They declared their religions as catholic $(42 \%)$, spiritist $(24.5 \%)$ and evangelic (13\%).

Insertion of academics in practical fields: suffering at work

After attending the first seven semesters of the undergraduate program, which include theoretical and practical activities (internships), the students return to campus in the eighth and ninth semesters for a full-time internship modality.

In the eighth semester, the student performs a workload of 1060 hours, working in healthcare centers, in the family health program, in hospitals and outpatient clinics, developing primary and secondary prevention activities with different human groups and distinct age groups.

In the ninth period, having advanced in some competences, the student performs another 1060 hours in units of higher complexity, such as: emergency, adult and neonatal intensive care unit, coronary unit, psychiatric, maternity, surgery room, surgery clinic and supervision in general hospitals. Students' average permanence in each context depends on their objectives, varying from one to three weeks.

In spite of the self-learning strategies adopted by the undergraduate course coordination, which include: programs with course objectives in each area; direct supervision by faculty members and evaluation systems that promote discussion and search for solutions for the problems faced on campus, there is no research on such educational problems at the institution.

The results of the present study are the product of an analysis of the situations the group experienced at work - used as a background - in order to discuss their own internship/work setting as a risk factor for the consumption of alcohol and other drugs.

The problems that contribute to the psychophysical exhaustion the academics mentioned include: moving from one campus to the other; lack of affinity with the type of work developed in these locations; poor work conditions; risk of exposure to biological materials; need to adapt quickly to the work pace of each internship location.

Students are "temporary workers" therefore, they are not a part of the effective staff of the institutions where they work as interns. Thus, their passage through the respective settings contributes 
to the suffering caused by work, due to the following: the short time spent at these locations, need to adapt quickly to the demands imposed by the organization, not always friendly experience with the teams, disqualification due to the lack of knowledge on some technologies and little familiarity with the work process.

The students are in a phase of knowledge acquisition, dealing with new situations. Work brings about tension and anxiety, as well as feelings of impotence, frustration and low self-esteem, mainly when their performance does not correspond to the faculty members', other workers', clients' or their own expectations.

While there is a degree of freedom between prescribed and real work for formal workers, which makes it possible to create coping strategies so they can keep their jobs despite the organization's demands ${ }^{(9)}$, for the students, this space is restricted. Contributing factors in this sense are inexperience, the need to follow what was established, fear of making mistakes and little previous experience, which does not always allow them to re-organize themselves in the face of new and unforeseen situations.

In view of this situation, the students depend more on the faculty and other workers, regarding the work process. This dependence increases due to the complexity of tasks and adversities.

Actual work incites the students to deal with a diversity of technologies related to healthcare, with work conditions, the environment and adversities. These adversities are linked to interpersonal relations because, as mentioned by the group, some team members, mainly from the nursing and medical careers, have already mastered the work process and sometimes demand knowledge, speed and decisionmaking that go beyond the students' capacities.

This experience of students in practical fields tends towards the classical concept of work with task division, imposed paces and prescribed methods, and especially division of personnel to guarantee the execution of the tasks represented by hierarchies, divisions of responsibility and control systems ${ }^{(9)}$.

From the students' point of view, work does not always correspond to the workers' expectations in terms of performance. There is an environment of animosity, little receptivity, apathy, irritation, demands and pressure to accomplish the task.

The position assumed by the faculty reproduces the demands of the organization with little flexibility, which can propitiate tension in the work environment, generate insecurity and lack of student motivation.

The faculty members are responsible for identifying the students' limitations in terms technical and interpersonal relations, mainly in situations demanding ready actions when dealing with the unpredicted, sharing the pain and suffering of the patients under their care ${ }^{(10)}$.

Psychophysical implications deriving from the intern's work at the health care unit

The nursing academic, when starting an internship program, develops theoretical-practical activities predicted in the full time curriculum. On weekend shifts, the student is under the supervision of a nurse, sharing the work with the local teams and experiencing administrative and assistance problems. Depending on the dynamics of the sector, work conditions and graveness of the clients, the workload and demands increase, which causes psychophysical exhaustion, mainly due to technology and little knowledge of the work process.

Therefore, it should be ratified that it is a great responsibility for the organization to maintain respectable work conditions for the nursing workers. Thus, a lot has to be done so that the health care worker's performance is correct and as free as possible from possible mistakes and accidents. In order to do so, training and updating, as well as good work conditions, are equally or even more important than technology itself ${ }^{(11)}$.

When questioned about how they felt about the many problems during their internships, the students complained about subjective aspects: irritation (33\%), anxiety (21.5\%), stress (21\%) and tension (19.7\%). Such expressions lean towards index-words like "painfulness". Work is painful when its context generates too much discomfort, effort or suffering, especially if the worker does not have control or capacity to intervene in the situations causing psychological suffering ${ }^{(3)}$.

Not only subjective, but also psychophysical complaints were identified: general tiredness (44\%), cluster headache $(21 \%)$, alterations of sleeping patterns $(19.5 \%)$ (insomnia or sleepiness during the day), dermatological problems (17.5\%) (peeling off, 
seborrheic dermatitis, alopecia), gastrointestinal problems (15\%) (diarrhea, constipation, cramps), moodiness (13.7\%) and body weight alterations, in some cases increased, in others lost (11.5\%).

The complaints about both objective and subjective points show that the students suffers from stress derived from work and study, and its manifestation among nurses permits understanding and clarifying some problems, such as professional dissatisfaction, work productivity, absenteeism, work accidents and some occupational diseases, as well as proposing interventions and searching solutions ${ }^{(12)}$.

It can be inferred that the work organization acts in the genesis of psychological suffering, leading to dissatisfaction and consequent aggression to psychological life, through some easily identifiable elements: long work hours, fast production pace, the clearly repressive and authoritarian pressure installed in a rigid and vertical hierarchy, inexistence or exiguity of breaks to rest along the shifts, lack of workers' control over the execution of work, alienation of work and worker, fragmentation of tasks and disqualification for the work performed ${ }^{(13)}$

Work in the health care units as a risk factor for the consumption of alcohol and other drugs

In the analysis of work as a risk factor for drugs consumption of, both objective and subjective conditions deserve attention. In this case, cognitive and affective dimensions stand out, which are inherent to the students' life history, values and wishes in the face of the work organization. Therefore, in order to think of prevention, individuals should be considered as subjects, in a given environmental, social, cultural and political context, and risk and related health protection factors should be studied ${ }^{(14)}$.

Considering the work context and its connection to the consumption of drugs, $47 \%$ of the students answered that, besides establishing the relations, work is so tiresome that the drugs are used as a relief valve or as a way to relax, due to the pressure they suffer in order to cope with the many activities.

When referring to the internship colleagues, $54.9 \%$ of the students affirmed that they ingest alcohol at parties and meetings to vent off, relieve stress and for pleasure; $9.8 \%$ reported that the consumption of cigarettes and alcohol increased when they were inserted in the internship program and 3.8\% knew about colleagues who used anxiolytics to sleep. The others $(17.6 \%)$ could not give an opinion; $9.8 \%$ did not establish a connection between working as a student and the consumption of drugs and $4.1 \%$ simply stated that they did not know whether their colleagues use drugs or not.

To apprehend the students' experiences related to drugs use, which may have occurred even before entering the university, a chart about the use and frequency of the main types of legal and illegal drugs was presented, so that the group participants could register their experiences.

After examining the chart, the students answered that $30 \%$ had already ingested alcoholic beverages; $88 \%$ used it occasionally, mainly in group meetings and parties; $19 \%$ used it frequently. When comparing the students from the $8^{\text {th }}$ and $9^{\text {th }}$ periods, the researchers noticed that the consumption of alcohol increased in the $9^{\text {th }}$ period on all items when they mentioned consumption, using it occasionally and/or always. It should be emphasized that, in the $8^{\text {th }}$ period, $17 \%$ of the academics claimed to have consumed alcoholic beverages, while all 27 students had had some kind of experience in the $9^{\text {th }}$ period.

Regarding cigarettes, 54\% never tried them, $25.5 \%$ had already tried and $13 \%$ smoked frequently. The experiences related to the consumption of cigarettes increased in the $9^{\text {th }}$ period, with a significant rise (tried, frequently use, always use). The last two items did not come up in the $8^{\text {th }}$ period.

Anxiolytics are mentioned as the third most frequently used legal drug, considering that $75 \%$ claimed not having tried them, 5.5\% had tried, $7.5 \%$ use them occasionally and $4 \%$ frequently. These results refer to the total number of students, regardless of the period they are in. However, it was observed that, in the $8^{\text {th }}$ period, only one student mentioned continuous use of anxiolytics, against 11 students in the $9^{\text {th }}$ period, while 15 use them sporadically and one student always.

The use of anxiolytics among students can be linked to the demands imposed by the job, when they mention irritation, anxiety and stress; $68.5 \%$ consider themselves dissatisfied with the sleep hours and $63 \%$ present sleep-related problems (insomnia, agitation during sleep and sleepiness during the day), along with irritability and decreased concentration.

Regarding illegal drugs, only marijuana was mentioned by $9.5 \%$ of the students, who claim having tried it, and $4 \%$ use it occasionally. Thus, alcohol, 
cigarettes and anxiolytics are the drugs more frequently used in the group, probably because they are easily accessible and better tolerated socially. With the exception of anxiolytics, media influence (television and movies) should also be considered, because it associates the use of alcohol and cigarettes with pleasure.

The risks of experiences related to drugs consumption were observed. By analyzing the natural history of the disease "dependence on psychoactive substances", the early stages of experimentation and sporadic use were recognized, in which the consumption of these drugs is almost always the individual's desire. At a certain moment, with the addiction to one or more substances, the "user" loses control over the consumption, becoming "dependent" when the desire to consume them becomes compulsive and sometimes irresistible, even after a period of abstinence $^{(15)}$.

Protective factors against drug consumption risks among healthcare work interns

The protective factors are part of a prevention policy against the use and abuse of drugs, with actions aiming to supply information and educate young people to adopt healthy habits that will protect their lives, hoping that these people do not use, decrease or stop consuming drugs. They must be encouraged to do it by schools and communities, with support from the State. Such factors are implemented and strengthened through a series of social and sports activities, which arouse the interest in reading, music, dancing, handicraft activities and sports among young people.

Traditionally, education has been the productive ground for prevention, but education alone will accomplish very little. It needs to join with the family and to receive community support in order to develop contextualized strategies, establishing social conditions and guaranteeing the best for everybody. The school, as the ideal space of prevention, has brought several methodologies, defining its role as an irradiation center of prevention actions for different social sectors ${ }^{(16)}$

Since young people are starting their undergraduate programs earlier and earlier (some are adolescents), the universities must have prevention policies that contemplate the protective factors through studies that consider the group's profile, habits, customs, knowledge about the phenomenon of drugs in society and how they apply this knowledge in their lives.

Within the protective factors the students mentioned, $60.7 \%$ look for some form of entertainment (walking around, traveling, watching TV, reading books, gardening, dating); $21.5 \%$ exercise (gymnastics), despite having little free time available and feeling tired; $17.6 \%$ choose resting. It is important to observe that $68.5 \%$ of the students feel dissatisfied with their sleeping hours. The importance of family support is ratified at this moment in education after all, it is in the family universe that affective exchanges happen, and these are remarkable for individuals and decisive in their way of being and acting towards themselves and others. The family is responsible for the transmission of social values and the caretaking functions of its members, who live together due to affectivity, taking over commitments of mutual care ${ }^{(17)}$.

\section{CONCLUSIONS}

Nursing students are vulnerable to the appeal of legal and illegal drugs, due to having their adolescence postponed because of studying, family dependence and late entry in the workforce.

The relation with work in the healthcare units of the city and the consumption of these drugs was mentioned as a way of minimizing the psychophysical exhaustion that results from the several academic activities, including work in practical contexts.

Besides academic activities, social activities can be risk factors, unsettling the balance among protective factors. Being with family, taking walks, dating, dedicating themselves to religion, physical activities, solving trivial problems or shopping are protective factors. A balance should be kept between these and academic activities because, depending on how demanding they are, they can increase psychophysical exhaustion.

Although the students report entertainment as a protective factor and a way of minimizing stress and distance themselves from everyday problems, they seek the use of alcoholic beverages and cigarettes in group meetings and parties. This attitude indicates that drugs, particularly legal substances, strongly appeal to the group, maybe due to greater tolerance, social acceptance and easy access.

Thus, the concept of risk, which prevention actions are based on, is not merely used to identify risk factors, since the mediation of intersubjective 
relations and concrete conditions of existence interfere with its understanding. It is important to analyze each situation in its own context, identifying the groups that are more exposed to these risks. The action focus, in this perspective, is the person, as a subject, and not the drugs for repression ${ }^{(18)}$.

Therefore, drug prevention among students should work with many factors that contribute to experimentation, such as individual characteristics, experiences before entering university, family and group contacts.

Recommendations include reinforcing protective factors like family support, exercising, maintaining physical space for reflection about the problems experienced in the internship fields as adopted by FENF/UERJ, the faculty members' support and the revision of teaching strategies.

\section{ACKNOWLEDGEMENTS}

Acknowledgements to the Inter-American Drug Abuse Control Commission/CICAD of the SubSecretary of Multidimensional Security at the Organization of American States/OAS, the Brazilian Anti-Drugs Secretary/SENAD, faculty members at the University of São Paulo at Ribeirão Preto College of Nursing, WHO Collaborating Centre for Nursing Research Development, Brazil, to the population who participated in the studies and to the representatives from eight Latin-American countries who participated in the I and II On-Line Specialization Program for Research CapacityBuilding on the Drugs Phenomenon-PREINVEST, offered in 2005/2006 by the University of São Paulo at Ribeirão Preto College of Nursing, as a distance education course.

\section{REFERENCES}

1. Martins CM, Pillon SC. Análise do programa Saúde da Família e o uso de álcool e drogas. In: Luis MAV, Pillon SC, organizadores. Assistência a usuários de álcool e drogas no Estado de São Paulo. Ribeirão Preto (SP): Fundação Instituto de Enfermagem de Ribeirão Preto; 2004. p. 105-10.

2. Martins ERC, Corrêa AK. Lidar com substâncias psicoativas: o significado para o trabalhador de enfermagem. Rev Latino-am Enfermagem 2004 março-abril; 12 (número especial):398-405.

3. Sato L. A representação social do trabalho penoso. In: Spink MJ, organizadora. O conhecimento no cotidiano: as representações sociais na perspectiva da psicologia social. São Paulo(SP): Brasiliense; 1995. p. 188-211.

4. Carrilo LLP, Mauro MYC. O Trabalho como fator de risco ou fator de proteção para o consumo de álcool e outras drogas. Texto \& Contexto Enferm 2004 abril-junho; 13(2): 217-25. 5. Braga VAB, Bastos AFB. Formação do acadêmico de enfermagem e seu contato com as drogas psicoativas. Texto \& Contexto Enferm 2004 abril-junho; 13(2):241-9.

6. Minayo MCS. O desafio do conhecimento: pesquisa qualitativa em saúde. 8. ed. São Paulo (SP): Hucitec; 2004. 7. Bardin L. Análise de conteúdo. Lisboa (PO): Edições 70; 1977.

8. Silva RC. Metodologias participativas para trabalhos de promoção de saúde e cidadania. São Paulo (SP): Vetor; 2002. 9. Dejours C. A psicodinâmica do trabalho: contribuições da escola djouriana à análise da relação prazer, sofrimento e trabalho. São Paulo (SP): Atlas; 1994.
10. Oliveira EB, Lisboa MTL, Lúcido VA, Sisnando SD. A Inserção do acadêmico de enfermagem em uma unidade de emergência: a psicodinâmica do trabalho. Rev Enferm. UERJ 2004 maio-agosto; 12(2):179-85.

11. Bulhões I. Riscos do trabalho de enfermagem. Rio de Janeiro (RJ): I. Bulhões; 1998.

12. Murofuse NT, Abranches SS, Napoleão AA. Reflexões sobre estresse e burnout e a relação com a enfermagem. Rev Lat-am Enfermagem Ribeirão Preto (SP) 2005 março-abril; 13 (2):255-61.

13. Seligmann-Silva E. Desgaste mental no trabalho dominado. Rio de Janeiro (RJ): Editora Cortez; 1994.

14. Caldeira ZF. Prevenção ideal versus prevenção possível. In: Inem C, Baptista M, organizadores. Toxicomanias: abordagem multidisciplinar. Rio de Janeiro (RJ): Editora Sette Letras; 1997.

15. Gobi RS, Giovannett BJP, Veloso HJ, Montanheiro ML, Pillon SC. Avaliando os riscos do uso de álcool e tabaco entre funcionários de um hospital público. In: Luis MAV, Pillon SC, organizadoras. Pesquisas sobre a prática da assistência a usuários de álcool e drogas no Estado de São Paulo. Ribeirão Preto (SP): Fundação Instituto de Enfermagem; 2004.

16. Laranjeira R. Prevenção do uso abusivo de drogas: conceitos básicos. São Paulo (SP): 2005.

17. Schenkerl M, Minayo MCS. A implicação da família no uso abusivo de drogas: uma revisão crítica. Ciênc Saúde Coletiva 2003; 8 (1): 299-305.

18. Bucher R. Prevenindo contra as drogas e DST/AIDS: populações em situação de risco. Brasília (DF): Ministério da Saúde. Programa Nacional de DST/AIDS; 1995. 